\title{
Locality in Humor Show entitled "Bocah Ngapa(K) Ya”
}

\author{
Shofi Mahmudah Budi Utami \& Muammar Kadafi \\ shofi.mahmudah.budi.utami@unsoed.ac.id \& muammar.kadafi@unsoed.ac.id \\ English Literature Department \& East Asian Languages and Literatures Department, \\ Universitas Jenderal Soedirman, INDONESIA
}

\begin{abstract}
This article discusses a humor show which was initially aired on YouTube channel entitled "Bocah Ngapa(K) Ya". This show particularly brings out humorous content with local dialects and exhibits local nuances of the Ngapakspeaking community. This phenomenological quality expressed by the Ngapakspeaking community as 'self' is understood as locality through which it connects the identity of the Ngapak-speaking community with a wider audience (global society). However, the locality displayed through such kind of shows can potentially perpetuate stereotyped identity. Thus, this article examines locality displayed in a particular humor show namely "Bocah Ngapa(K) Ya" which offers an alternative identity of the Ngapak-speaking community. Central to the analysis is an argumentation that the depiction of Ngapak people in "Bocah Ngapa(K) Ya" subverts their stereotyped identity. The purpose of this study is to reveal hierarchical identities and to present an alternative to view this local identity based on the local context and humor delivery in the humor show. The method employed is cultural studies approach in order to view this cultural phenomenon. Through this study, it is found that the locality performed in this humor indicates a contemporary identity for the Ngapak people in the current era, which posits Ngapak people beyond their prevailing identity.
\end{abstract}

Article information

Received:

7 July 2020

Revised:

20 October

2020

Accepted:

26 October

2020

Keywords: Ngapak; humor; locality; identity

\section{Introduction}

The theme of locality becoming an outburst on the YouTube platform has been varied in quantity. For example, Epen Cupen (MOP Papua) is a representation of the people from East Indonesia namely Papua; this content introduced Eastern Indonesian-style humor in 2016. Another one is Tumming Abu which represents humor style from Celebes, particularly Makassar. Beside those two examples, current humor content that brings out locality as a theme in 2018-2019 is entitled "Bocah Ngapa(K) Ya"; this has raised consciousness of the local nuances of the Ngapak-speaking community in Central Java. 
Compared to MOP Papua and Tumming $A b u$, "Bocah Ngapa(K) Ya" has been the only content which is screened on TV and has been a weekly show program. It seemed to confirm that this humor which performs locality becomes a popular content. This is also construed that it has been greatly accepted by the Indonesian spectacle regardless of its local language. Among these two contents mentioned above, "Bocah Ngapa(K) Ya" always uses mixed languages, both local language and Indonesian language, which probably makes it popular since it is still understandable. The examples suggest people's taste in light entertainment and humor content with a particularly local nuance. It leads to presuppositions about the essence of locality within humor, whether the locality that is carried in humor is to obviously elevate local values existing in a particular society, or the locality constructed through the spectacle is a humor set in a hierarchical position. Apart from these two presuppositions, the emergence of humor with local nuance has remained to be very popular in society since the outburst of various platforms including YouTube.

To further investigate locality, this study considers the locality concept drawn by Appadurai, who stated that locality is realized through performance, representation, and human action known as 'cultural space' (Appadurai, 2005; Donelly, 2017). At a glance, "Bocah Ngapa(K) Ya" is potential for celebrating the locality of the Ngapakspeaking community through the spectacle. Following Appadurai's concept of locality, the cultural space manifested in this humor might celebrate the local identity of the Ngapak people by exposing Ngapak's culture existing in the community. Furthermore, Tsakona stated that humorous texts usually involve identities related to ethnics, politics, religion, gender, etc. that can be expressed via electronic media (Tsakona, Okras and the metapragmatic stereotypes of humor, 2013). In linking this idea, the identity attached to Ngapak people can be observed through this humorous text, "Bocah Ngapa(K) Ya". Based on previous research, the identity of Ngapak's people is associated with the image such as marginalised people compared to Javanese people in general or particularly Javanese people from Yogyakarta and Surakarta (Pawestri, 2019). Thus, "Bocah Ngapa(K) Ya" is potential to delineate contemporary identity which is associated with the Ngapak-speaking community in the context of current era; that it is probably a counter to the earlier Ngapak people's identity.

Therefore, this issue is very interesting to be studied more deeply, particularly about the presence of locality in popular culture which is tricky to define when it is located in the context of popular culture. According to Raymond Williams (Williams in Prado) popular culture has two criteria: closeness to the audience (because of its relationship with 'popularity') and having no distinctive/special character such as those cultures of elite arts and culture; or what Williams calls 'aesthetic inferiority'. Thus, the locality seems to actually be contradictory to the concept of popular culture. Aside from its attaching characteristic to popular culture, Fiske points out that the core of popular culture is how it generates meaning within a social system where a set of allegiances move fluidly (Fiske, 2007). Following Fiske's idea, the humor show is not merely seen as a product of culture unless this circulation of product can generate meanings within the society. It is more appropriate to view how the humor show makes sense by celebrating a certain group's identity rather than locating the humor show based on aesthetic quality.

The problem of locality is central because this study aims to trace the identity of the Ngapak-speaking community revealed through the perception of local nuance in the cultural space. So far, the identity of the Ngapak-speaking community represented through the TV shows by such figures including Cici Tegal and some actors in "Tuyul dan Mbak Yul" series has been positioned as inferior to those people in the city. This issue has been so hierarchical since they are doubly subordinated. First, they are subordinated to those people living in the city and secondly to those who are Javanese excluding the Ngapakspeaking community (people who speak 
Semarangnese, Solonese, and Yogyanese variety of Javanese-they are called 'mbandhek'-speaking community) (Pawestri, 2019).

The Ngapak-speaking community demographically includes those people who live in the western part of Central Java covering regions such as Kebumen, Banyumas, Banjarnegara, Purbalingga, Cilacap, and Tegal-therefore, they are also called speaking western Javanese dialect (Kartika, 2019). Based on the language aspect, for example, some lexica and sounds in the Ngapak Javanese variety do not exist in the Mbandhek Javanese variety (Pujiyatno and Poejosoedarmo, 2008). Thus, Ngapak people are considered different from those of people speaking another variety of Javanese. Ngapak people use different dialect which has raising tones and highpitched sounds; they speak loudly with clear meaning and simple sentence; also they pronounce clear sounds of the vocal [a], [o], consonant [b], [d], [k], [g], [h], [y], [l], and [w] (Kartika, 2019).

According to the culture, these two communities are arguably dissimilar; and they are, in such a way, stereotyped to be different. Ngapak people tend to be, stereotypically, expressive; that is why most of them are attached to the image of 'being who they are' because of the way they speak; they speak the word exactly like what is written (Kartika, 2019) - that is why they are characterized as expressive and genuine (Pawestri, 2019). This stereotype could be both meant positive as they could be genuine; and negative as they might be rude in some way because of their expressiveness. However, with all these characters/differences and stereotypes, it asserts that Ngapak peoples have their own local culture. They express their locality through, particularly, their language.

Due to its contrasting character, the Ngapak-speaking community has been demarcated to those of people from Mbandhek-speaking community. Thus, the objective of this research is to present findings of the perspective of locality, especially the Ngapak-speaking community; and alternative identity offered through the humor content. With the presence of these findings, this research is expected to be able to specifically contribute to the discipline of the humanities and contribute to other scholarship in shaping perceptions and interpretations of cultural phenomenon locally and globally.

Other than that, this research is worth discussing since there is still a lack of reference toward the study of identity and locality represented by entertainment shows especially in the context of the Ngapak community. Some previous studies about humor or entertainment shows are present but they are researched from different disciplines including Linguistics and Literature; one example is the article written by Eka Noftriana, Dwijani Ratnadewi, and Armeria Wijaya (2014) discussing Stand-Up comedy by Raditya Dika which uses flouting maxims in the statements of the comic to create jokes within comedy performance. This is particularly about language use in making the content of humor.

Another research is by a scholar from the University of Wollongong named Hanae Katayama (2009) who examined comedy performance in the U.S and Japan based on the commonalities and differences in culture in delivering the comedy. This research is specifically about cross-cultural communication between the comedian performers and the audiences since culture can be a boundary to deliver humorous remarks. Within the same scope, Yue and Hiranandani (2014) investigated crosscultural perception towards humor and being humorous, to primarily examine the difference that relates to humor. More importantly, this research indicated that there are differences, which are culturally bounded, in perceiving humor and being humorous according to participants in Hong Kong, Hangzhou, and Vancouver. The participants in Hong Kong and Hangzhou perceived themselves as less humorous than those people in Vancouver.

Besides, Jeffrey Hall (2017) discussed humor associated with relationship satisfaction; this study was conducted with the 
quantitative method of interviewing respondents in perceiving humor within a relationship. The result of Hall's research is that positive types of humor are respected positively and consequently negative types of humor are also respected negatively. Another discussion about humor was also researched by Hani Fatmawati (2013) who focused her study to investigate the construction of humor and to identify the function of the humor within the literary texts. She viewed that humor in the literary works is constructed by the narrator in delivering significant meaning and inviting reactions from the readers; while the function of the humor is to create laughter which is assumed as the reader's response to the humor.

Aside from the findings presented earlier, Caparoso and Collins (2015) indicated that within the context of university or higher education, social stratification delivered through humor still exists and potentially perpetuates the stereotype of a certain group (ethnic or racial group). The investigating humor situated in a university context by Caparoso and Collins contributes to the view that the role of institution developed the perpetuation of these ethnic-based stereotypes. By this finding, humor can be a latent and pervasive vehicle in this perpetuation of ethnic-based stereotypes.

Accordingly, due to the previous research do not particularly subsume the locality within the humor; and they also do not discuss specifically the Ngapak-speaking community, this article intends to uncover the cultural phenomenon of the Ngapak-speaking community within the humor content; how their identity is perceived through the humor; and also how "Bocah Ngapa(K) Ya contributes to present different perception of the Ngapak people's identity in order to counter the prevailing stereotyped identity.

\section{Methodology}

Cultural studies is mainly centered on how culture is constituted with meanings and representations in the context of human practices (Barker, 2002); one of the features in this cultural studies is the subjective dimension of social relations by which complex intersections can be configured and made sense of (Pickering, 2008). Connecting to this understanding, popular culture as one of the features implied earlier articulates this potential to further understand the complexity of social relations or arrangements in the social worlds we live in.

Since this research is about the cultural phenomenon in the local community portrayed in the video, it also belongs to the scope of cultural studies. So, it is appropriate to approach the problem of how the humor show as a product of popular culture generates construction through which representation constitutes meanings. Moreover, those representations are shared with others, which is crucial to our changing identities or conceptions towards the social worlds (Pickering, 2008). Cultural studies provides a pattern of signifying practices in constituting the meanings. Thus, the process of making sense of Ngapak people representation in "Bocah Ngapa(K) Ya" videos will be understood by selecting and grouping texts under the central problem; such as the form or content in the video through its visual depictions, narration, and also the style of humor delivery which draw to the matter of locality. More importantly, this locality is made sense of to potentially consider another conception towards the identity of Ngapak people.

Central to the analysis, this study is framed based on several ideas. Firstly, it is focused on the text namely the videos of "Bocah Ngapa(K) Ya"; this is how the displays such as visual text and narration (through dialog) are examined through its cinematography entity and utterances which represent a portrait of the Ngapak-speaking community. This step views the importance of displays such as colors, light, characters, and their roles through their utterances that possibly give meaning to the interpretation.

Secondly, it is focused on humor delivery. Particularly, the pattern of a punchline in the humor is identified to further analyze possible 
assumptions that surround this humor. The third step is examining the second level of signification (connotation). Here, the focus is on the typical representation of the Ngapakspeaking community that is presented from the videos.

\section{Results and Discussion}

\section{A local context for the Ngapak people}

"Bocah Ngapa(K) Ya" was initially humor content on a Youtube channel named "Polapike" which sounds very local by the use of Javanese language, Ngapak variety. Based on its title, "Polapike" can be translated as "very good" or "extremely good". Later on, the title "Bocah Ngapa(K) Ya" is given because it was finally screened on one of the Indonesian TV stations. Since it has been a weekly program aired on TV, accordingly, the term 'content' and 'show' can be used interchangeably in referring to this humor.

This humor show is typically set as a situational comedy which has similar primary casts from episode to episode, consisting of four characters namely Ilham, Fadly, Azkal, and Pak RT. This also showcases local nuance by using Javanese language, Ngapak dialect in delivering the humor; but sometimes, they speak both Ngapak Javanese and Indonesian language interchangeably. It also has a narrative form which is wrapped in a local theme such as departing from daily matter and being set in a local setting as well.

In linking to the above description of the content in "Bocah Ngapa(K) Ya", overall this humor show delineates a salient notion of Ngapak people who embrace their heritage, especially speaking their accent and being close to nature. The following pictures are some shots depicted at the beginning of almost every episode. The videos always start with an aerial view of the countryside. Based on these pictures taken from different episodes signify that this humor show affirms the local nuance in the humor; to some extent, these aerial views contextualize the Ngapak-speaking community who are mostly tied to their farming culture and closeness to nature.

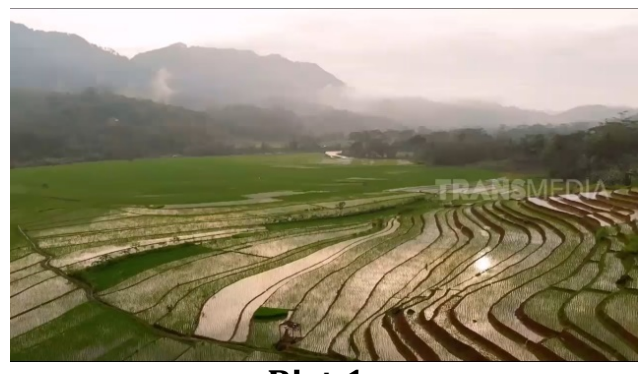

Pict.1

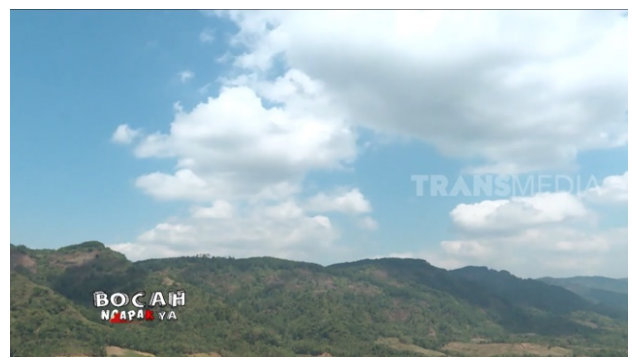

Pict. 2

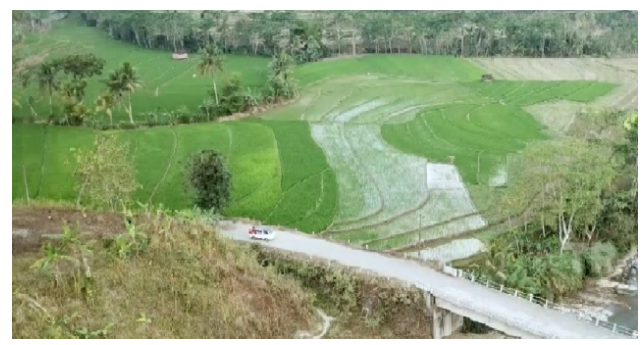

Pict. 3

All of these depictions at the beginning of the story in the video are deliberately an exposure of their realities. Thus, in line with the theme in the humor, the jokes depart from simple matters such as daily activities, daily conversation as natural as it happens in real life: about helping, misunderstanding, and helping with misunderstanding. Furthermore, the videos are mostly taken in daylight which may depict cheerfulness and happiness that humor aims to bring out. The narrative form is always put in the context of how people in the countryside are engaged with each other such as being sociable, sharing both difficulties and help, being simple and straightforward, which is also a character of Ngapak people (Pawestri, 2019). The humor is then delivered through this narrative by using primarily Javanese language with Ngapak dialect which is associated with their local identity. They also use Indonesian language interchangeably in order to be well grasped without losing its entertaining side. 
Besides the narrative, the characters acted by the main casts also embody the local character in Javanese puppetry, namely punokawan. The characters represented in "Bocah Ngapa(K) Ya" are seemingly adapted from these punokawan characters. Pak RT (a person who is elected to be the representative/leader/head in the neighborhood) is presumably close to the character of Semar; the three sons adopted by Semar can be seen through these three children namely Ilham, Fadly, and Azkal. The roles played by these casts are also nearly similar as played by punokawan although it is slightly adapted here, for instance, the role of Pak RT is the one who is trusted and somehow respected as an elder figure; thus, the characterization of Semar is represented by Pak RT. It is exemplified by this dialog between Pak RT and Ilham.

Pak RT: Heh, pertandingan karo kampong sebelah, nyong duwe strategi kiye.

Azkal: Strategine keprimen kiye pak RT?

Pak RT: kaya kiye, nyong arep ngeduna pemain utama disit, Azkal, Fadli, ilham.

Ucup : Lah nyong kepriwe pak RT?

Pak RT : Untuk sementara Ucup urung medun disit. Pokoke mudune nunggu nyong prentah.

Pak RT: Well, I have a strategy for our match with the next-door village.

Azkal: How is it then, Pak RT?

Pak RT: I'd like the major players including Azkal, Fadli, and Ilham to enter the game from the first minute.

Ucup: How is it going with me?

Pak RT: I'll keep Ucup to not come on, you'll enter the game later. Just wait for the order to do so.

In this scene, Pak RT becomes the one who is trusted as the coach for their team. The order given by Pak RT seems like he is an elder whose advice should be believed by the younger generation. Furthermore, the visualization of Pak RT is represented with a bigger posture and acted by a man who is definitely older than these three boys. Specifically in this scene, Pak RT was sitting among the boys and stayed in the middle. This suggests his position that is respected while he was explaining his strategy for a football match.

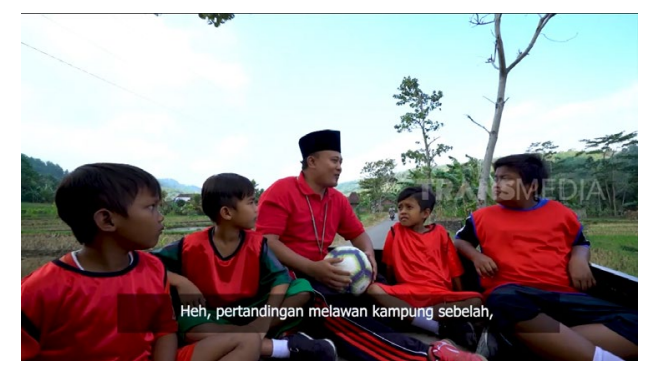

Pict. 4

Even though Pak RT is not a total resemblance to Semar, it embodies a part of his characterization adapted from the figure of Semar who plays a central role in Javanese culture. This, again, asserts local value inserted in this humor show. Through these aspects including cultural and social traits (such as closeness to nature, the use of Ngapak dialect, being straightforward or genuine and embodying punokawan's character) contextualize the Ngapak people in the humor.

\section{The Style of Humor}

Based on the humor delivery, the way the casts deliver the humor is by using pun rather than slapstick or body shaming technique. The pun in humor is familiar to give humorous effect; by employing a word that has double or even multiple meanings, so that the audience will respond to it both by thinking and laughing. Because the pun sometimes gives a halt to think of its relation with another meaning, it firstly sounds simple but the audiences won't probably think as simple as it is presented in the dialog. The clips of "Bocah Ngapa(K) Ya", for example, showcases a sort of misunderstanding between Pak RT and Ilham about the word "bawahan" which has more than one meaning. This clip tells about Pak RT who needs an assistant to help him with the job as Pak RT. This scene uses the word 'bawahan' which could give two possible meanings namely 'assistant' and 'an outfit (bottom)'. 


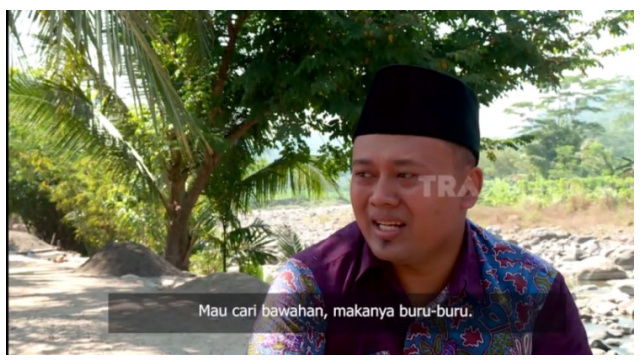

Pict. 5

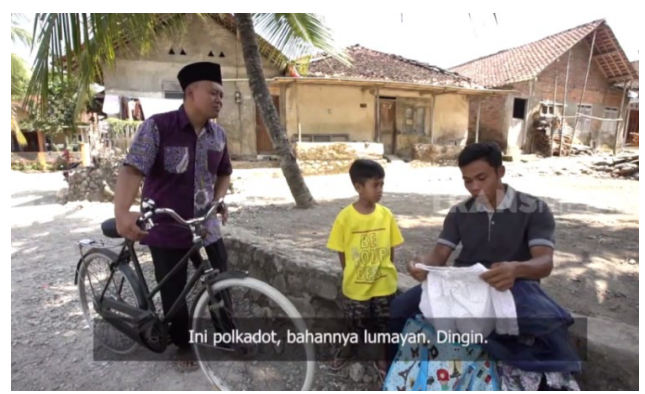

Pict. 6

When one word has possibly multiple meanings, the context is then used to distinguish them. However, this humor intelligently plays with the word 'bawahan' to give the audience a second to think about the context. Then, the role of Pak RT here lets the audience put the word in a specific context which means 'assistant'. Later on, the ending of this clip shows that Ilham thought that this 'bawahan' means an outfit. This misunderstanding is presented through the pun by using the word 'bawahan'. Beside presenting the pun in the humor, this also depicts innocence that might also occur among the society, not only by kids but also by adults.

Another example is in this clip which exemplifies a dialogue when Ilham, Fadly, and Azkal were studying together accompanied by a private tutor at home. In this scene, these three kids were learning about proverbs in Bahasa Indonesia. One by one, they had to understand what the meaning of the proverb is. When it came to Ilham to grasp one proverb as it says "Semut di seberang laut Nampak, gajah di pelupuk mata tak nampak" or "ant across the sea is clearly seen while an elephant on the eyelids is invisible", he undoubtedly answered what he knew about the proverb by answering "it's a person who suffers from long-sightedness (hyperopia)". In this scene, the audience might not think of that literal answer; and this innocence by decoding the proverb literally does make sense, but, in fact, it is an unexpected answer. This innocence and unexpectedness are a good combination in the pun; thus, it makes the humor alive.

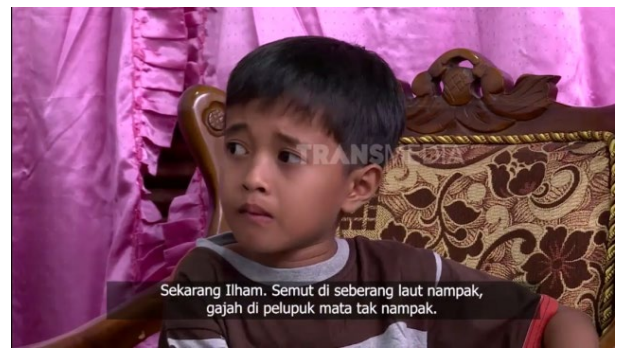

Pict. 7

This innocence also exemplifies an image of local people who are mostly stereotyped through film or video; as such Ngapak people are attached with this particular image of being innocent and are also tied with their origin of local place. On the other hand, the image of innocence further signifies, more importantly, the character of Ngapak people as people who would say what they want to say and are considered straightforward. This meaning extends the identification of Ngapak people's identity by viewing from within and no longer contrasting them with other group's identity. It strongly suggests that their identity is, through the humor, constituted beyond the earlier stereotype; that Ngapak people are adhered with their being local associated in their genuineness character.

In correlating with another aspect, in particular, the use of the pun in this humor is always arranged for its punchline. This is arguably considered smart humor because instead of using slapstick or body shaming, it uses a pun to confuse meaning to give a humorous effect. As Canestrari and Bianchi suggest that there are three main perspectives in dividing humor namely relief, superiority, and incongruity (Canestrari \& Bianchi, 2013) which locates this kind of humor is not merely in giving entertainment (relief) and does not denigrate people's identity by attaching to stereotypes (superiority). Therefore, this 
humor can be seen from incongruity perspective which works on verbal humor presenting ambiguity. By operating this ambiguity with which situation is perceived as a unit provides two alternative interpretations.

The ambiguity is served by the pun operated in the humor style by "Bocah Ngapa(K) Ya"; it always provides alternative interpretation in the intended words for the punchline. Thus, the humor delivered in the videos elevates the position of the Ngapakspeaking community, especially their identity, that they present a smart joke. In addition, this style of humor also asserts that their identity is no longer bound with the hierarchical position. This alternative identity offered by the depictions of Ngapak people in "Bocah Ngapa(K) Ya" somehow counters the stereotyped identity of the Ngapak speakingcommunity who are always portrayed as inferior (Pawestri, 2019).

\section{Locality in "Bocah Ngapa(K) Ya"}

From these two clips, it can be argued that the locality shown in this humor is through its innocence of the people in the countryside; and it is expressed through the pun. In line with the issues about locality and identity, it can be said that the locality of a particular region represents a certain group of people. In Java, there are various kinds of local people who come from different regions; they are connected through a space within society. A particular space, which is not fixed or flexible, is called social space, in which localization is connected through social relations among the community (Nick Prio in Donnelly, 2017). Localities constructed within the social space are potential to produce social products (Donnelly, 81). What is understood as a social product, in Donnelly's opinion, is a 'construct' rather than a formation; the example is identity. This relates to the locality that is constructed by social space such as television shows or shows on the YouTube platform. In this case, the identity of the Ngapak-speaking community constructed through television and humor show is being produced and reproduced through repetition-sometimes it is potential to be false as it is taken for granted, such as the Ngapak people were identified as inferior to major Javanese people; therefore, this 'construct' may lead to a repetitive form to eventually become a 'stereotype'; which is then conceived as 'real'; because the stereotype is the identity constructed from the outside (Vickers, 1998; Setyaningsih, 2013). Otherwise, "Bocah Ngapa(K) Ya" presents identity associated with alternative perspectives in viewing the locality of Ngapak people-the identity is viewed from within, based on their cultural and social traits and their style of humor. That is why the identity of the Ngapak people is beyond their earlier identity, in order to counter its prevailing stereotype.

The repetitive stereotype of the Ngapakspeaking community as inferior, depicted in previous electronic media as mentioned previously, perpetuates the Ngapak identity under the hegemonic discourse. Otherwise, "Bocah Ngapa(K) Ya" tries to subvert this false identity by the depictions of Ngapak people's locality and style of humor; they assert that the prior identity as an inferior is a timeless truth. This alternative of viewing Ngapak people's identity is very crucial to reshape a new understanding of their contemporary identity in this current era.

\section{Conclusion}

Humor shows in the context of popular culture indicate a reversal meaning to which is previously defined. Based on the show entitled "Bocah Ngapa(K) Ya", the identity of the Ngapak-speaking community which was offered previously is no longer stable; but instead, it is potential to counter the prior stereotyped identity and offer an alternative identity for the Ngapak-speaking community. The identity of the Ngapak-speaking community, which was previously defined based on its binary opposition and through its previous stereotype, is reconstructed by displaying any possibilities for the identity. Society is no longer defined based on the identity of other local communities or dominant communities, but they are defined 
based on the existence of the Ngapak-speaking community themselves as a local community among others; who are able to see themselves from within-what constitutes themselves as being in the Ngapak-speaking communitytheir locality.

In addition, through their locality and the humor delivery, this humor show affirms an alternative to defining the Ngapak-speaking community by contextualizing their local existence in these social worlds. Their locality perceived through their cultural and social traits suggests their identity in a more factual and contemporary. Furthermore, the style of humor which operates word-logic performed in the humor is perceived as incongruity-based humor, which is intelligently marked as dense humor. Thus, "Bocah Ngapa(K) Ya" delineates the ability of the Ngapak-speaking community to perform such dense humor which posits their community and their identity out of the previous stereotype. Therefore, what is represented through this humor show negotiates Ngapak's local identity by giving out an alternative which counters its previous local identity.

\section{References}

Allen, M., \& R, S. (2007). Popular Culture, Globalization, and Japan. London and New York: Routledge.

Appadurai, A. (2005). Modernity at Large: Cultural Dimension of Globalization. Minneapolis: The University of Minnesota Press.

Barker, C. (2002). Making Sense of Cultural Studies: Central Problems and Critical Debates. London: SAGE Publication Ltd.

Canestrari, C., \& Bianchi, I. (2013). From Perception of Contraries to Humorous Incongruities. In M. Dynel, Develompents in Linguistic Humor Theory (pp. 3-5).
Philadelphia: John Benjamin Publishing Company.

Caparoso, J. T., \& Collins, C. S. (2015). College Student Racial and Ethnic Stereotypebased Humor as Cultural Domain. Power and Education, 7(2), 196-223.

Comaroff, J., \& Comaroff, J. (1992). Ethnography and The Historical Imagination. Colorado: Westview Press.

Donelly, L. (2017). Producing Space and Locality Through Cultural Displays: A Creole Case Study. SAGE journals, 20(1), 81-93.

Fatmawati, H. (2014, January 27). Reconstructing Humor: An Analysis of Humor in Two Selected Short Stories. Retrieved December 10, 2019, from Repository Indonesia University of Education: http://repository.upi.edu/4740/

Fiske, J. (2007). Understanding Popular Culture. New York: Routledge.

Hall, J. (2017). Humor in Romantic Relationship: A Meta-analysis. Journal of The International Association for Relationship Research, 1-17.

Kartika, S. (2019). The Viewer's Perception to Dialect Banyumasan English to Dialect Banyumasan English VLOG by Click Sinau. Surakarta: IAIN Surakarta.

Katayama, H. (2009). A Cross-cultural Analysis of HUmor in Stand-Up Comedy in the United States and Japan. JoLIE, 2(2), 125142.

Noftriana, E., Ratnadewi, J., \& Wijaya, A. (2014). An Analysis of Flouting Maxims to Create Humor in Stand Up Comedy by Raditya Dika. TELL Journal, 2(2), 37-42.

Pawestri, A. G. (2019). Membangun Identitas Budaya Melalui Dialek Ngapak di Media Sosial. Jurnal Pendidikan Bahasa dan Sastra, 19(2), 255-266. 
Pickering, M. (2008). Research Methods for Cultural Studies. Edinburgh: Edinburg University Press.

Polapike, R. (Director). (2019). Bocah Ngapa(K) Ya [Motion Picture]. Sadangwetan, Jawa Tengah.

Prado I.M.S. (2016) "Lo popular"/Popular Culture: Performing the Borders of Power and Resistance. In: Martínez-San Miguel Y., Sifuentes-Jáuregui B., Belausteguigoitia M. (eds) Critical Terms in Caribbean and Latin American Thought. New Directions in Latino American Cultures. Palgrave Macmillan, New York

(DOI

https://doi.org/10.1057/978113754790 3_24)

Pujiyatno, A., \& Poedjosoedarmo, S. (2008). Variasi Dialek Bahasa Jawa di Kabupaten Kebumen (Kajian Sosiodialekologi). LEKSIKA, 2(1), 14-23.

Setyaningsih, N. (2013). Ethnic Stereotypes in Stand-Up Comedy. The 5th International Conference on Indonesian Studies: Ethnicity and Globalization (pp. 144-157). Jakarta: Universitas Indonesia.

Tsakona, V. (2013). Okras and the Metapragmatic Stereotypes of Humor. In M. Dynel, Developments in Linguistic Humor Theory (p. 25). Amsterdam and Philadelphia: John Benjamin Publishing Company.

Vickers, S. B. (1998). Native American Identities: From Stereotype to Archetype in Art and Literature. New Mexico: University of New Mexico Press.

Yue, X. D., \& Hiranandani, N. A. (2014). Perception of humorists: A Cross-cultural Study of Undergraduates in Hong Kong, Hangzhou, and Vancouver. Comprehensive Psychology, 1-5. 